\title{
Medicinal plant extracts on the control of Diabrotica speciosa (Coleoptera: Chrysomelidae)
}

BARBOSA, F.S.; LEITE, G.L.D.*; MARTINS, E.R.; D'AVILA, V.A.; CERQUEIRA, V.M.

UFMG, Insetário G.W.G. de Moraes, Instituto de Ciências Agrárias, Avenida Universitária, n. 1000, Bairro Universitário, Caixa Postal 135, CEP: 39404-006, Montes Claros, MG - Brasil. *gldleite@ig.com.br

\begin{abstract}
RESUMO: Extratos de plantas medicinais no controle de Diabrotica speciosa (Coleoptera: Chrysomelidae). O objetivo deste trabalho foi avaliar o efeito inseticida de extratos aquosos, alcoólicos e oleosos de folhas de oito plantas medicinais contra Diabrotica speciosa preparadas em cinco concentrações. Os extratos que utilizaram óleo de soja comercial como solvente apresentaram as maiores mortalidades de $D$. speciosa em função do próprio óleo, independentemente das plantas utilizadas em suas concentrações. Sendo assim, o óleo de soja comercial foi descartado como solvente, pois nestes volumes acarretaria sérios problemas de fitotoxidade. Após 24 horas de exposição da praga aos extratos, os maiores valores de mortalidade de $D$. speciosa foram observados nos extratos de Copaifera Langsdorfii e de Chenopodium ambrosioides, ambos em álcool 5\%, e de Artemisia verlotorum, em água 10\%. Entretanto, na última avaliação de mortalidade (48 h), o extrato de C. langsdorfii em álcool a $5 \%$ apresentou maior mortalidade dessa praga, seguida pelo extrato alcoólico a $5 \%$ de $C$. ambrosioides comparada às demais plantas.
\end{abstract}

Palavras-chave: Ruta graveolens, Artemisia verlotorum, Stryphnodendron adstringens, Baccharis trimera, Copaifera langsdorffii

\begin{abstract}
The aim of this study was to evaluate the insecticidal effect of aqueous, alcoholic, and oil extracts from leaves of eight medicinal plants against Diabrotica speciosa prepared at five concentrations. The extracts that used commercial soybean oil as solvent showed the highest $D$. speciosa mortality due to the solvent itself, regardless of the used plants and their concentrations. Thus, commercial soybean oil was discarded as solvent since at these volumes it would cause serious phytotoxicity problems. After 24 hours of exposure of the pest to the extracts, the highest $D$. speciosa mortality values were observed for Copaifera langsdorfii and Chenopodium ambrosioides extracts, both in $5 \%$ alcohol, and Artemisia verlotorum, in $10 \%$ water. However, in the last mortality assessment (48 h), C. langsdorfii extract in $5 \%$ alcohol showed higher mortality of this pest, followed by $\mathrm{C}$. ambrosioides extract in $5 \%$ alcohol, compared to the remaining plants.
\end{abstract}

Key words: Ruta graveolens, Artemisia verlotorum, Stryphnodendron adstringens, Baccharis trimera, Copaifera langsdorffii

\section{INTRODUCTION}

Diabrotica speciosa (Germar) (Coleoptera: Chrysomelidae) is a pest that affects several crops in Brazil. The young forms of this insect feed on roots, while the adults feed on leaves, green beans or fruits, reducing the productivity; the main control method is the use of synthetic organic insecticides (Gallo et al., 2002).

However, the need to control pests, reducing negative impacts on the environment, as well as on the man, induces the search for alternative pest control methods, such as the use of plant extracts (Viegas Júnior, 2003; Trevisan et al., 2006), which may favor natural enemies, necessary for the biological balance (Gallo et al., 2002). Plants, including medicinal ones, contain several active compounds, as is the case for Ruta graveolens L. (Rutaceae), Artemisia abisinthium L. and $A$. verlotorum L. (Asteraceae), Stryphnodendron adstringens Mart. (Leguminosae), Baccharis trimera Less. (Asteraceae), Copaifera langsdorffii Desf. (Leguminosae), Petiveria alliacea

Recebido para publicação em 12/12/2010

Aceito para publicação em 04/02/2013

Rev. Bras. PI. Med., Botucatu, v.15, n.1, p.142-149, 2013. 
L. (Phytolaccaceae) and Chenopodium ambrosioides L. (Chenopodiaceae). These plants have shown an effect against insects, mollusks, bacteria etc (Mendes et al.,1984; Almeida et al., 1999; Echevarría \& Idavoy, 2001; Lapenna et al., 2003; Oliveira et al., 2005; Silva et al., 2005; Chaithong et al., 2006; Ishida et al., 2006; Leite et al., 2006). However, studies of insect control by using plant extracts are poorly known and, in general, use expensive and toxic extractors such as methanol (Morales-Cifuentes et al., 2001; Benevides et al., 2001; Lapenna et al., 2003) and hexane (Morales-Cifuentes et al., 2001). These experiments used essential oil, the extraction of which demands sophisticated equipment, frequently incompatible with the farmers' reality. Therefore, plant extracts must be tested for their insecticidal effect, as well as to determine the best extraction method that maintains the major chemical compounds, the ideal concentrations, the ease of preparation, the involved costs and the safety to the farmer.

The aim of this study was to determine the best extraction method and concentration of some medicinal plants that have organic compounds with insecticidal properties against $D$. speciosa.

\section{MATERIAL AND METHOD}

This experiment was carried out at the Institute of Agrarian Sciences of Univ Federal de Minas Gerais (ICA/UFMG)" from October to December 2006. Experimental design was completely randomized, with four replicates. Each replicate consisted of a Petri dish $(10 \times 2 \mathrm{~cm})$ with 10 $D$. speciosa adults (unknown sex and age), collected from an organic bean crop and incubated at $25^{\circ} \mathrm{C}$ for mortality assessment after 24 and 48 hours.

The plants $R$. graveolens, $A$. verlotorum, A. absinthium, B. trimera, P. alliacea and $C$. ambrosioides were organically cultivated at the Medicinal Garden of ICA/UFMG, and C. langsdorffii and $S$. adstringens trees were already present in ICA/UFMG Campus, on dystrophic red latosol of medium texture. Some extracts were prepared with commercial soybean oil to extract non-polar compounds and others were prepared with water or alcohol to extract polar compounds from the plants (Barbosa, 2000).

Three extraction methods were tested for each plant: 1) $25 \%$ leaf fresh weight from the medicinal plant $(25 \mathrm{~g}$ plant $)+100 \%$ distilled water $(100 \mathrm{ml})$. The leaves were cut into small pieces, placed in amber glass flasks, which soon received boiling water and were covered (Tea). After cooling, the tea was filtered and stored in an amber glass flask until used. 2) $25 \%$ leaf fresh weight from the medicinal plant $(25 \mathrm{~g}$ plant $)+100 \%$ commercial hydrated ethyl alcohol $(100 \mathrm{ml})$. The leaves were cut into small pieces, placed in an amber glass flask, which soon received the alcohol and was agitated twice a day, during 15 days. After this period, the solution was filtered and again stored in an amber glass flask until used. 3) $20 \%$ dry weight (20g plant) $+100 \%$ commercial soybean oil $(100 \mathrm{ml})$. The leaves of the medicinal plants were allowed to dry at $40^{\circ} \mathrm{C}$ for $48 \mathrm{~h}$ and ground until powder was obtained. The mixture was heated in water bath for $2 \mathrm{~h}$, in an amber glass flask. After cooling, the extract was filtered and again stored in an amber glass flask until used.

After each extract was obtained from the study plants, four concentrations were tested: 2, 5, 10 and $15 \%$ of the volume of each extract. An apical bean leaflet was immersed, for two seconds, in each concentration of the extracts. This leaflet was kept in the shadow and open air, for two hours, until evaporation of the excess water. Subsequently, 10 $D$. speciosa adults were placed on Petri dishes (10 $x 2 \mathrm{~cm}$ ) for mortality assessment after 24 and $48 \mathrm{~h}$. As controls, two procedures were used: in the first procedure, $10 \mathrm{D}$. speciosa adults were placed on the bean leaflet, and in the second procedure the bean leaflet was submerged in the solvent used in the extraction process, adopting the same drying procedure and replicates. Aqueous and oil extracts were used soon after cooling, while alcoholic extracts were used at 15 days after the preparation.

The obtained data underwent analysis of variance, and means were compared according to Scott-Knott test and regression analysis, at 5\% significance. To assess the best extraction method and the best concentration for each plant, mortality was not corrected by the control, since it could show higher mortality of the solvent in relation to the concentrations, resulting in negative mortality. After the best concentration and extraction method had been determined, mortality was corrected with the control (solvent).

\section{RESULTS AND DISCUSSION}

For extracts prepared with commercial soybean oil, controls (solvent) showed high $D$. speciosa mortality; the same was noted for the extracts of the studied plants at the different concentrations ( 100\%), except for B. trimera, which had mortality of around 35\% (Figures 1 to 4 ). The controls (solvent) were even better or did not significantly differ from the tested concentrations of the studied plants in the different exposure times (Figures 1 to 4). In general, when the concentrations of the extracts that used oil as solvent increased, mainly at the concentrations of 10 and/or $15 \%$, $D$. speciosa mortality was high, probably due to the presence of the oil and not of the secondary 
compounds of these plants (Figures 1 to 4). On the other hand, the tendency to lower mortality, in general at the lowest concentrations (2 and 5\%), was possibly due to the oil dilution, at 24 and 48 hours of evaluation, for the different plants (Figures 1 to 4). The obtained results indicate that the use of commercial soybean oil as extractor is not recommended because the high mortality is due to the solvent and not to the active compounds of


plants; besides, phytotoxicity problems may affect the plants or decrease gas exchanges $\left(\mathrm{CO}_{2} / \mathrm{O}_{2}\right)$ in the stomata, impairing photosynthesis under field conditions, as observed for mineral oil (Koller et al., 1999).

The extracts of $R$. graveolens, $A$. verlotorum, A. absinthium, $P$. alliacea, $S$. adstringens, B. trimera and $C$. ambrosioides, at the different concentrations obtained with water or alcohol, showed low $D$.
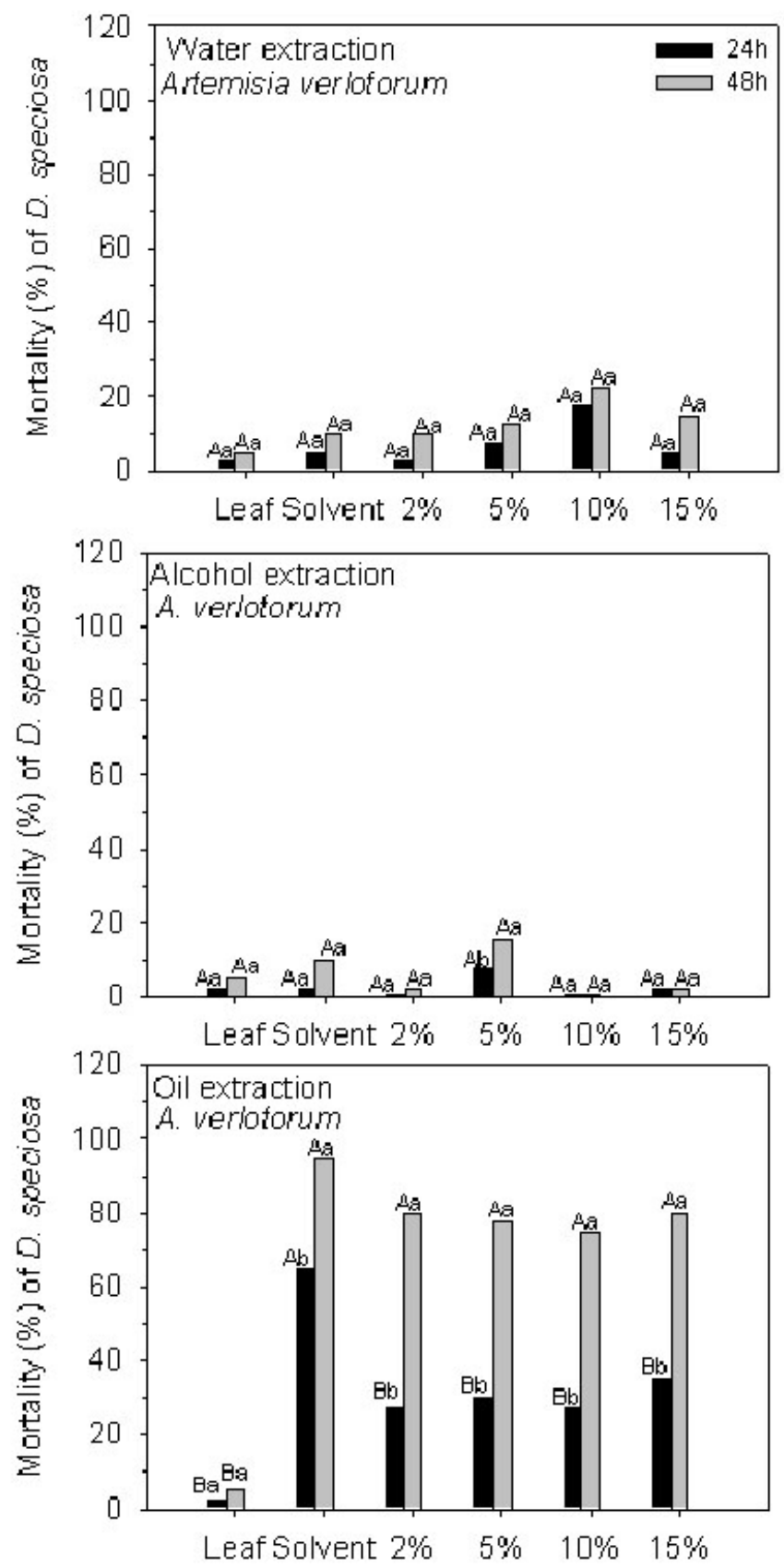

\section{Treatments}

FIGURE 1. Effect of concentrations of Ruta graveolens and Artemisia verlotorum plant extracts on the mortality percentage of Diabrotica speciosa adults after 24 and 48 hours. Mean followed by the same capital letter, comparing treatments, and lowercase letter, comparing the hours, do not differ, according to Scott-Knott test $(P<0.05)$. 

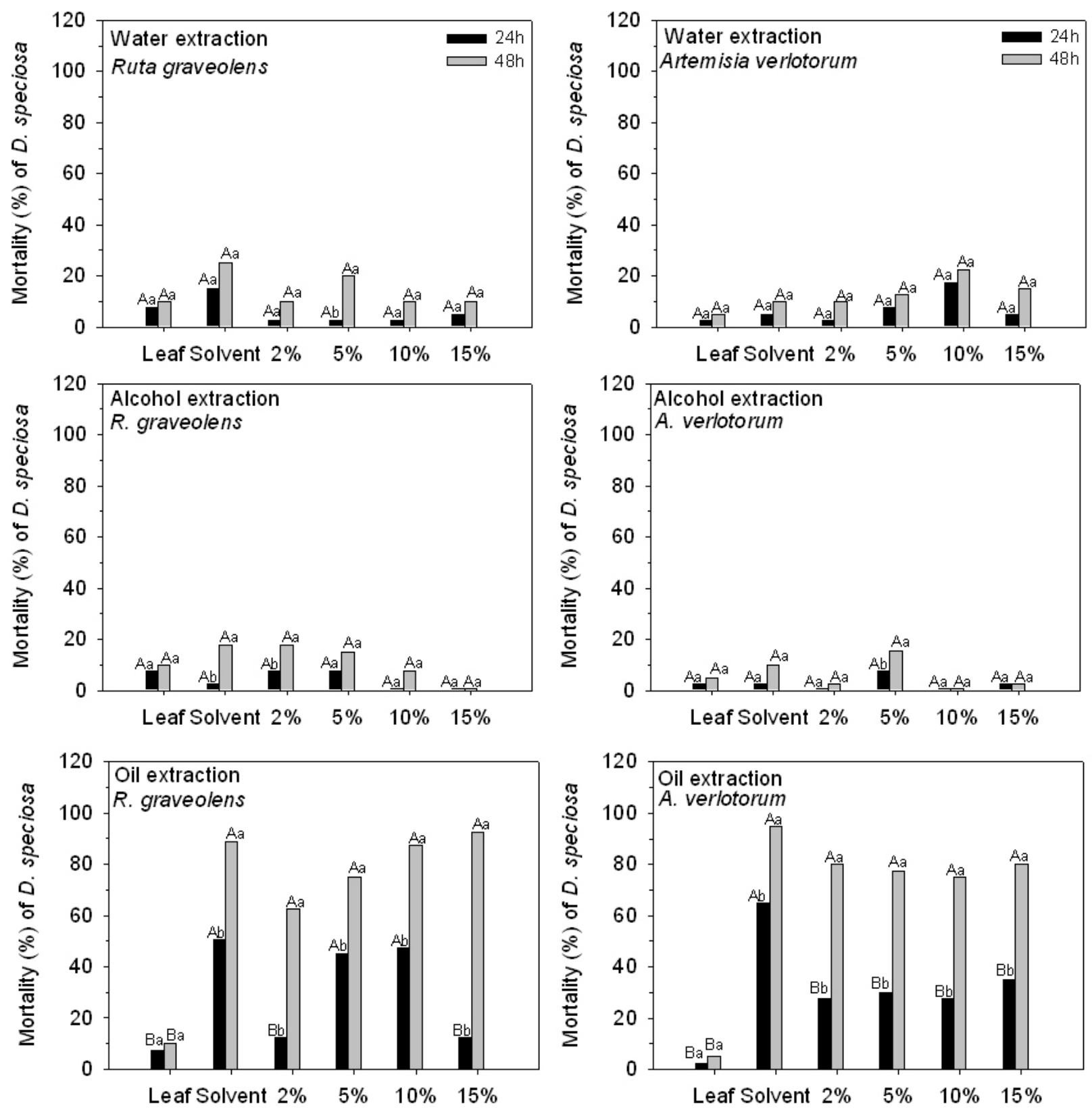

Treatments

FIGURE 2. Effect of concentrations of Petiveria alliacea and Stryphnodendron adstringens plant extracts on the mortality percentage of Diabrotica speciosa adults after 24 and 48 hours. Means followed by the same capital letter, comparing treatments, and lowercase letter, comparing the hours, do not differ, according to Scott-Knott test $(P<0.05)$.

speciosa mortality, not differing from the controls that used the respective solvents or only leaves (Figures 1 to 4). Mortality was then corrected by the control (solvent) to compare the ideal concentration of the best extraction method for each plant, the concentrations that showed larger mortality numbers compared to control were chosen, as well as the least expensive plants or solvent. However, C. langsdorfii presented significantly higher mortality, at the concentration of $5 \%$, using alcohol as extractor (Figure 3). After 24 hours of exposure, the highest corrected $D$. speciosa mortality was observed for C. langsdorfii and C. ambrosioides extracts, both in $5 \%$ alcohol, and $A$. verlotorum extract, in $10 \%$ water (Figure 5). However, in the last mortality evaluation (48 h), C. langsdorfii extract showed higher mortality, followed by $C$. ambrosioides, compared to the other plants (Figure 5). Besides, according to the equation 

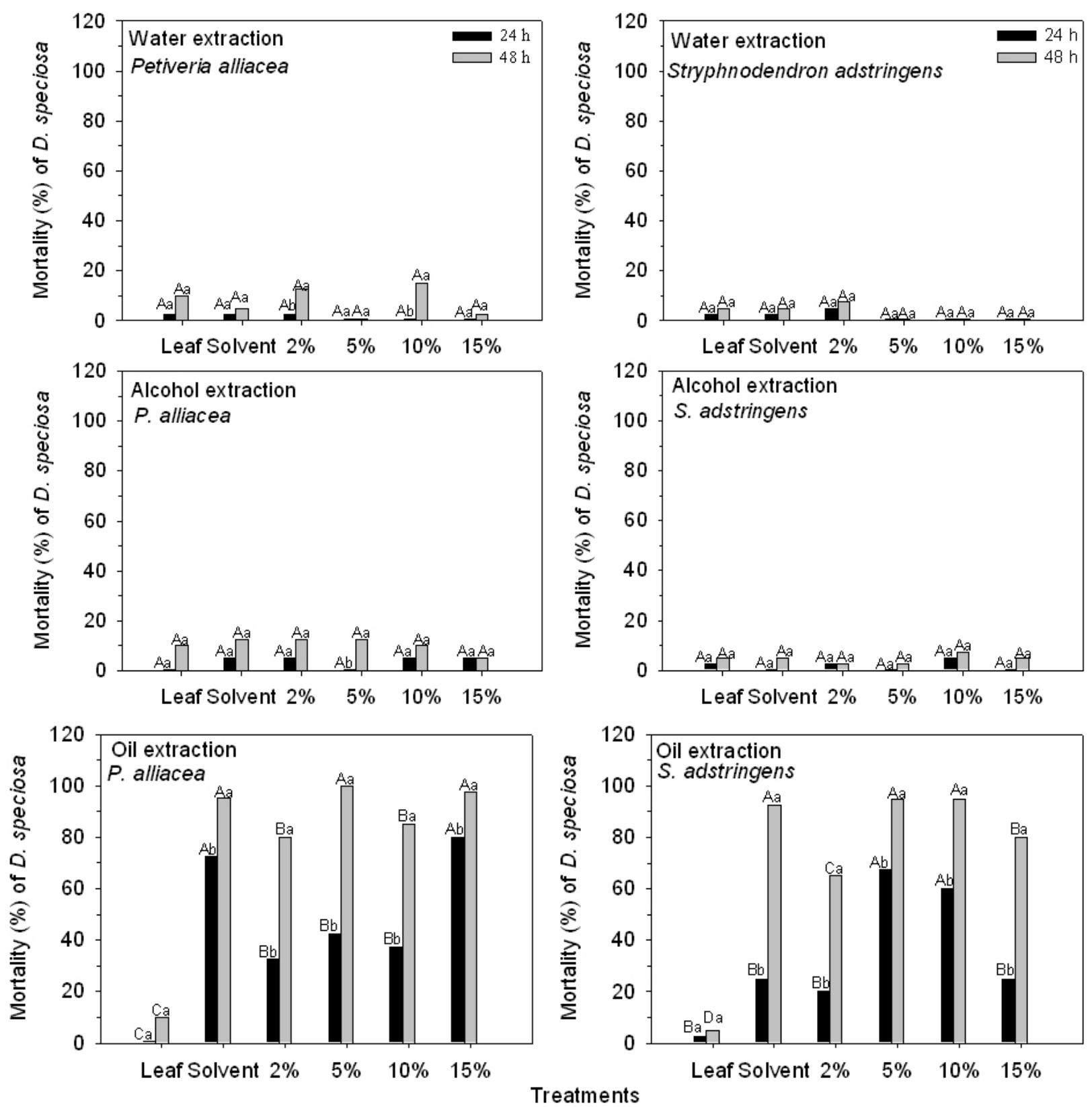

FIGURE 3. Effect of concentrations of Baccharis trimera and Copaifera langsdorfii plant extracts on the mortality percentage of Diabrotica speciosa adults after 24 and 48 hours. Means followed by the same capital letter, comparing treatments, and lowercase letter, comparing the hours, do not differ, according to Scott-Knott test $(P<0.05)$.

$y=-1.45+7.76 x\left(R^{2}=0.56\right)$, for the alcoholic extract of C. langsdorfii to kill 50 and $99 \%$ of $D$. speciosa adults, within $48 \mathrm{~h}, 6.63 \%$ and $12.95 \%$ of this extract would be necessary. For $C$. ambrosioides extract in alcohol $(48 \mathrm{~h})\left(\mathrm{y}=-0.53+4.87 \mathrm{x} ; \mathrm{R}^{2}=0.28\right), 10.38 \%$ and $20.44 \%$ would be necessary to kill 50 and $99 \%$ $D$. speciosa adults, respectively. The best results obtained for $C$. langsdorfii, as insecticide plant, may be due to the presence of coumarin (Viegas Júnior \& Pinto, 2002), showing effect against Aedes aegypti L. larvae (Diptera: Culicidae) (Chaithong et al., 2006). The mortality obtained with $C$. langsdorfii extract was of approximately $40 \%$, demonstrating to be promising in the control of pests, since Calafiori \& Barbieri (2001) observed mortality of around $50 \%$ D. speciosa by using the insecticide thiamethoxam. As already shown for C. ambrosioides, the flavonoids and terpenoids in its leaves (Cruz et al., 2006) could be responsible for its insecticidal action, as also verified by Silva et al. (2005) against Sitophilus zeamais 

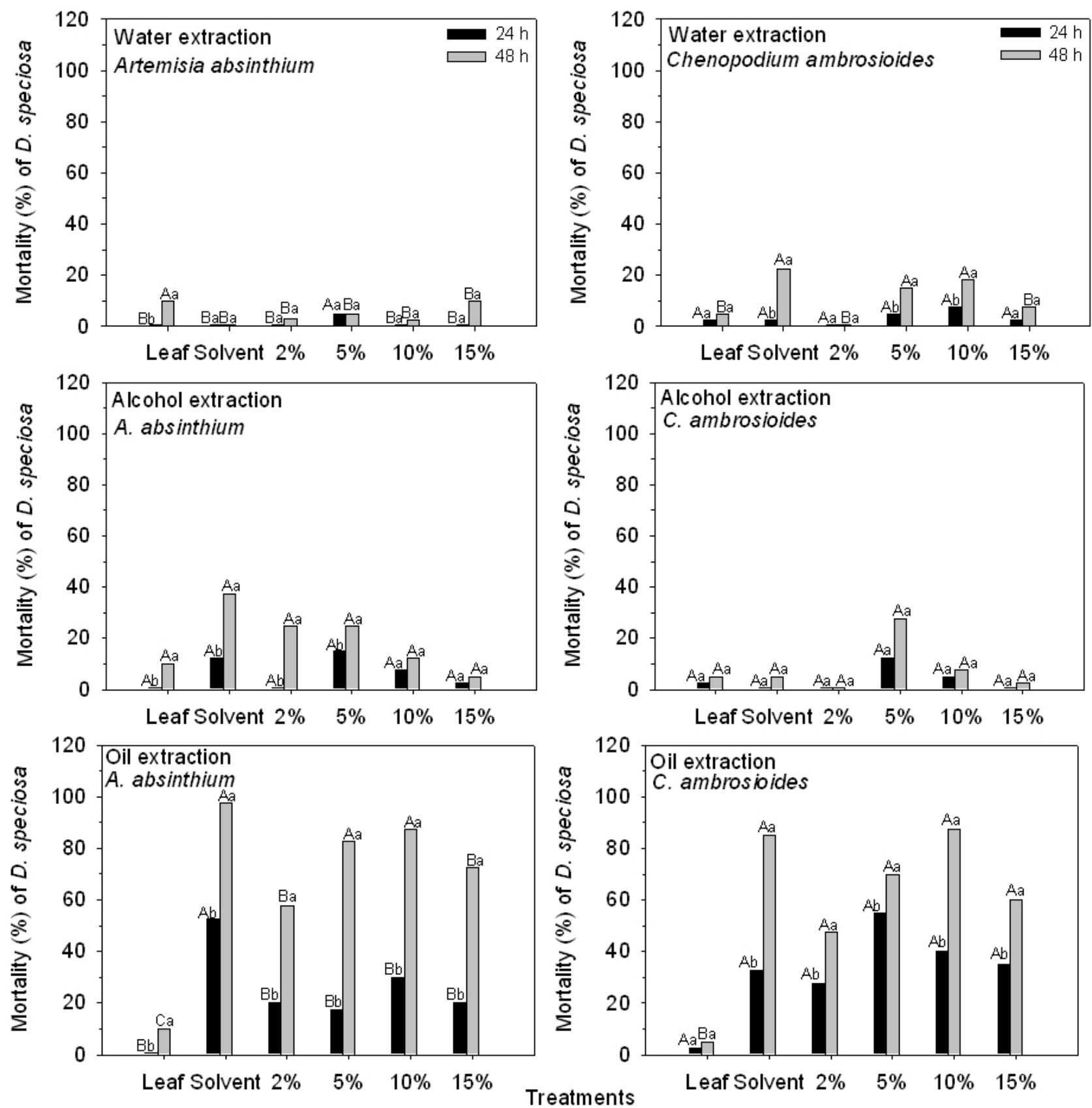

FIGURE 4. Effect of concentrations of Artemisia absinthium and Chenopodium ambrosioides plant extracts on the mortality percentage of Diabrotica speciosa adults after 24 and 48 hours. Means followed by the same capital letter, comparing treatments, and lowercase letter, comparing the hours, do not differ, according to Scott-Knott test $(P<0.05)$.

Mots. (Coleoptera: Curculionidae). The other studied plants did not show insecticidal effect, probably due to the used extraction methods. $R$. graveolens has flavonoids (rutin and hesperidin), coumarin, alkaloids (rutacridone, rutalidine, rubalinidine), and essential oil (2-nonanone, 2-decanone, 2-undecanone, 2-dodecanone, 2-tridecanone, myrcene, limonene, terpinolene, 2-nonyl acetate, 3-docyl acetate, 2-octyl acetate, 2-nonanol, 2-undecanol, naphthalene)
(Fredj et al., 2007; Martins et al., 2005). These compounds are probably responsible for the insecticidal effects observed for S. zeamais (Almeida et al., 1999) and Ctenocephalides canis Curtis (Siphonaptera: Pulicidae) (Leite et al., 2006).

Mendes et al. (1984) verified that the hexanic extract of $A$. verlotorum leaves at $100 \mathrm{ppm}$ showed effect against eggs, with $100 \%$ mortality of embryos, while the alcoholic extract of this plant 
killed $90 \%$ of the adults of Biomphalaria glabrata Say (Mollusca: Planorbidae), probably due to the sesquiterpenes and lactones found in this plant (Kelsey \& Shafizadeh, 1979). These compounds have shown repellent and insecticidal effect to Spodoptera littoralis Boisduval (Lepidoptera: Noctuidae) (Viegas Júnior, 2003). Another plant of the same genus, A. absinthium, showed $100 \%$ mortality of $C$. cannis, when the latter was exposed, for 10 minutes, to the infusion of the leaves of that plant (Leite et al., 2006), which is rich in essential oil containing terpenes and absinthin (Omer et al., 2007).

The methanol extract of $P$. alliacea presents effect against the protozoan Trypanosoma cruzi Cruz (Kinetoplastidae: Tripanosomatina), the cause of Chagas's disease, (Cáceres et al., 1998), as well as antimicrobial activity (Lapenna et al., 2003), while its ethanol extract (30\%) has negative effect on the growth of Giardia lamblia Kunstler (Diplomonadida: Hexamitidae) in vitro (Echevarría \& Idavoy, 2001). The suppression of those microorganisms is probably due to the action of secondary compounds in $P$. alliacea including coumarin, triterpenes, flavonoids, amine acids (Benevides et al., 2001), essential oil, petiverine, resinous acid (LopesMartins et al., 2002). A triterpene extracted from Azadirachta indica A. Juss. (Meliaceae) inhibits the feeding of insects, affecting the larval development, reducing the fecundity and the fertility of adults, altering the behavior, and causing several anomalies in the cells and in the physiology of insects; it also causes mortality of eggs, larvae and adults, such as in Oligonychus ilicis McGregor (Acari: Tetranychidae) and in Iphiseiodes zuluagai Denmark and Muma (Acari: Phytoseiidae) (Martinez, 2002; Mourão et al., 2004). Trevisan et al. (2006) verified that flavonoid glycosides, obtained in the hydroalcoholic extract of Kalanchoe brasiliensis Camb. (Crassulaceae), show inhibitory effect of cholinesterase on $A$. aegypti $\mathrm{L}$. (Diptera: Culicidae).

S. adstringens has from 10 to $37 \%$ tannin in its constitution (Holetz et al., 2005). This compound shows an action against Candida albicans (Robin) Berkhout (Saccharomycetales: Saccharomycetaceae), as well as moderate fungicide activity, similarly to the action of the chemical product Nystatin (Holetz et al., 2005; Ishida et al., 2006). Tannin is capable of inactivating digestive enzymes and creating a tannin-protein compound of difficult digestion for the insects (Cavalcante et al., 2006).

Finally, B. trimera extract shows activity against Staphylococus aureus Rosenbach (Bacillales: Staphylococcaceae), at a low bactericidal concentration of $25 \mathrm{mg} / \mathrm{ml}$ (Oliveira et al., 2005). Verdi et al. (2005) verified that plants of the

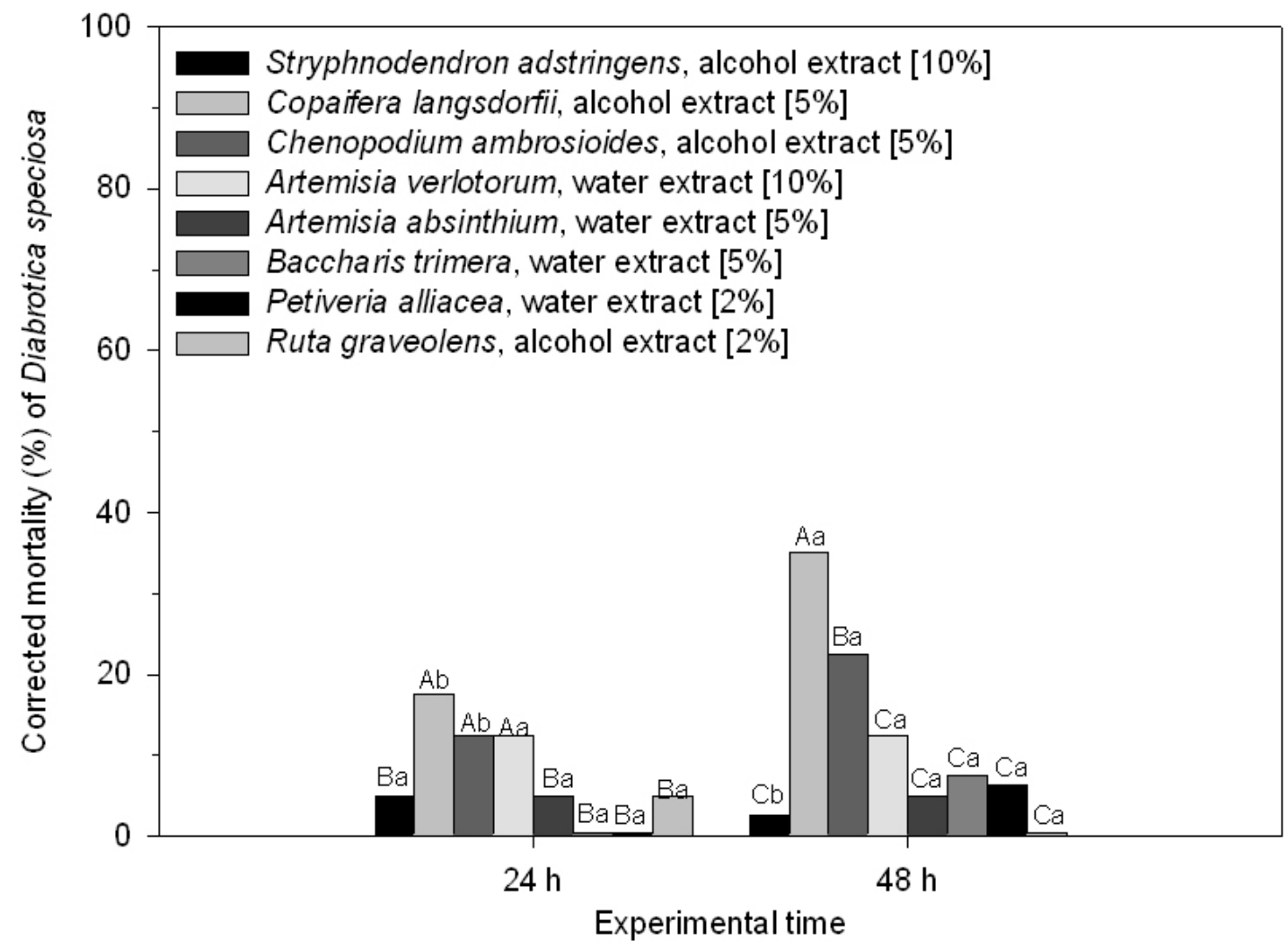

FIGURE 5. Corrected mortality (\%) of Diabrotica speciosa in different plant extracts. Means followed by the same capital letter, in the same group, or lowercase letter, among groups of histograms, do not differ, according to Scott-Knott test $(P<0.05)$.

Rev. Bras. PI. Med., Botucatu, v.15, n.1, p.142-149, 2013. 
genus Baccharis have flavonoids, diterpenes and triterpenes, while $B$. trimera shows saponins. The saponins represent the main terpenoid group, are toxic and deterrent for herbivores in general (Cavalcante et al., 2006); seemingly, its insecticidal action is due to the inhibition of acetylcholinesterase in the insects (Viegas Júnior, 2003).

In summary, alcoholic extracts of $C$. langsdorffii and $C$. ambrosioides, at the concentration of $5 \%$, show insecticidal effect against $D$. speciosa. The extraction method is simple and cheap.

\section{ACKNOWLEDGMENT}

The authors thank CAPES, CNPq and FAPEMIG for research support.

\section{REFERENCE}

ALMEIDA, F.A.C. et al. Avaliação de extratos vegetais e métodos de aplicação no controle de Sitophilus spp. Revista Brasileira de Produtos Agroindustriais, v.1, n.1, p.13-20, 1999.

BARBOSA, L.C.A. Química orgânica: Uma introdução para as ciências agrárias e biológicas. Viçosa: UFV, 2000. 354p. BENEVIDES, P.J.C. et al. Antifungal polysulphides from Petiveria alliacea L. Phytochemistry, v.57, n.5, p.743-7, 2001.

CÁCERES, A. et al. Plants used in Guatemala for the treatment of protozoal infections. I. Screening of activity to bacteria, fungi and American trypanosomes of 13 native plants. Journal of Ethnopharmacology, v.62, n.3, p.195202, 1998.

CALAFIORI, M.H.; BARBIERI, A.A. Effects of seed treatment with insecticide on the germination, nutrients, nodulation, yield and pest control in bean (Phaseolus vulgaris L.) culture. Revista Ecossistema, v.26, n.1, p.97-104, 2001.

CAVALCANTE, G.M. et al. Potencialidade inseticida de extratos aquosos de essências florestais sobre moscabranca. Pesquisa Agropecuária Brasileira, v.41, n.1, p.9-14, 2006.

CHAITHONG, U. Et al. Larvicidal effect of pepper plants on Aedes aegypti (L.) (Diptera: Culicidae). Journal of Vector Ecology, v.31, n.1, p.138-44, 2006.

CRUZ, G.V.B. et al. Increase of cellular recruitment, phagocytosis ability and nitric oxide production induced by hydroalcoholic extract from Chenopodium ambrosioides leaves. Journal of Ethnopharmacology, v.111, n.1, p.14854, 2006.

ECHEVARRÍA, A.; IDAVOY, D.T. Efecto de um extrato de Petiveria alliacea lin sobre el crescimento de Giárdia lamblia in vitro. Revista Cubana Médica Militar, v.30, n.3, p.161-5, 2001.

FREDJ, M.B.H. et al. Analysis of Tunisian Ruta graveolens L. oils from Jemmel. Journal of Food, Agriculture \& Environment, v.5, n.1, p.52-5, 2007.

GALLO, D. et al. Entomologia agrícola. Piracicaba: FEALQ, 2002. 920p.

HOLETZ, F.B. et al. Biological effects of extracts obtained from Stryphnodendron adstringens on Herpetomonas samuelpessoai. Memórias do Instituto Oswaldo Cruz, v.100, n.4, p.397-401, 2005.

ISHIDA, K. et al. Influence of tannins from Stryphnodendron adstringens on growth and virulence factors of Candida albicans. Journal of Antimicrobial Chemotherapy, v.58, n.5, p.942-9, 2006.

KELSEY, R.G.; SHAFIZADEH, F. Sesquiterpene lactones and systematics of the genus Artemisia. Phytochemistry, v.18, n.10, p.1591-611, 1979.

KOLLER, O.C. et al. Frutificação precoce de laranjeiras 'monte parnaso' com anelagem e pulverizações de ácido giberélico e óleo mineral. Pesquisa Agropecuária Brasileira, v.34, n.1, p.63-8, 1999.

LAPENNA, M.E.A. et al. Actividad bactericida y fungicida de algunas plantas utilizadas en la medicina tradicional venezolana. Revista del Instituto Nacional de Higiene Rafael Rangel, v.34, n.1, p.6-9, 2003.

LEITE, G.L.D. et al. Efeito de boldo chinês, do sabão de côco e da cipermetrina na mortalidade de pulgas em cachorro doméstico. Revista Brasileira de Plantas Medicinais, v.8, n.3, p.96-8, 2006.

LOPES-MARTINS, R.A.B. et al. The anti-Inflammatory and analgesic effects of a crude extract of Petiveria alliacea $\mathrm{L}$. (Phytolaccaceae). Phytomedicine, v.9, n.3, p.245-8, 2002. MARTINEZ, S.S. O NIM Azadirachta indica: natureza, usos múltiplos, produção. Londrina: Instituto Agronômico do Paraná, 2002.142p.

MARTINS, A.G. et al. Levantamento etnobotânico de plantas medicinais, alimentares e tóxicas da llha do Combu, Município de Belém, Estado do Pará, Brasil. Revista Brasileira de Farmácia, v.86, n.1, p.21-30, 2005.

MENDES, N.M. et al. Ensaios preliminares em laboratório para verificar a ação moluscicida de algumas espécies da flora brasileira. Revista Saúde Pública, v.18, n.5, p.348-54, 1984.

MORALES-CIFUENTES, C. et al. Neuropharmacological profile of ethnomedicinal plants of Guatemala. Journal of Ethnopharmacology, v.76, n.3, p.223-8, 2001.

MOURAO, S.A. et al. Selectivity of neem extracts (Azadirachta indica A. Juss.) to the predatory Mite Iphiseiodes zuluagai (Denmark \& Muma) (Acari: Phytoseiidae). Neotropical Entomology, v.33, n.5, p.613-7, 2004.

OLIVEIRA, S.Q. et al. Screening of antibacterial actvity of South Brazilian Braccharis species. Pharmaceutical Biology, v.43, n.5, p.434-8, 2005.

OMER, B. et al. Steroid-sparing effect of wormwood (Artemisia absinthium) in Crohn's disease: A double-blind placebo-controlled study. Phytomedicine, v.14, n.2-3, p.87-95, 2007.

SILVA, G. et al. Búsqueda de plantas con propiedades insecticidas para el controlde Sitophilus zeamais en maíz almacenado. Pesquisa Agropecuária Brasileira, v.40, n.1, p.11-7, 2005.

TREVISAN, M.T.S. et al. Atividades larvicida e anticolinesterásica de plantas do gênero Kalanchoe. Química Nova, v.29, n.3, p.415-8, 2006.

VIEGAS JUNIOR, V.F.; PINTO, A.C. O gênero Copaifera L. Química Nova, v.25, n.2, p.273-86, 2002.

VIEGAS JUNIOR, C. Terpenos com atividade inseticida: uma alternativa para o controle químico de insetos. Química Nova, v.26, n.3, p.390-400, 2003.

VERDI, L.G. et al. Gênero Baccharis (Asteraceae): aspectos químicos, econômicos e biológicos. Química Nova, v.28, n.1, p.85-94, 2005. 